\title{
CASA ESSAY
}

The essay competition is sponsored by the Classical Association of South Africa. This paper was judged to be the best student essay submitted to CASA for 2012.

\section{'SCILICET HORRORES PUTARES' OPPOSITION TO SAME-SEX MARRIAGE IN THE EARLY EMPIRE}

\author{
Claude F Heyman, BA Hons. Classical Studies (University of South Africa)
}

The early Empire has become almost a locus celeberrimus for popular histories of same-sex marriage, and the attraction is not difficult to understand. Regardless of polemical allegiance, the activist who chooses to focus on the occurrences of such a practice in the early Empire is afforded two advantages. Firstly, Christianity had not yet become an influential moral code in mainstream society, and therefore arguments for the acceptance or rejection of the practice gain extra weight from being non-sectarian. Secondly, the depictions and verbal forms in the extant literature are unambiguous, so there is no need for evidential pleading. Yet a clear cut answer to the question 'Did the Romans have gay marriages?' is surprisingly unhelpful. If one says yes, does it mean that Roman society fully condoned the practice? If one says no, does it mean that homosexuality was opposed by the common populace? The texts that have come down to us depicting same-sex marriage and the opposition which they detail are not simple and simple answers will likewise not suffice. Yet even in academia, lines are sometimes drawn too quickly. As Richlin summarizes: ${ }^{1}$

A review of the literature in the field shows a dialogic process, in which statements at one extreme produce opposing statements; probably all could be modified. Jasper Griffin writes in opposition to the New Critical approach that denies any reality to the homoerotic expressions in Roman texts. Ramsay MacMullen argues that the mainstream of Roman culture deplored all forms of homosexuality, to counter John Boswell's thesis that Rome condoned homosexuality. David Cohen, among others, on the Greek side and I on the Roman side respond to the Foucaultian attempt to define ancient sexuality as completely separate from modern. Perhaps the most important conclusion to take away from all these studies is what comes out in the surveys of ancient material: these cultures were not monolithic.

$1 \quad$ Richlin 1993:571. 
It should be clear that extreme positions on the topic of same-sex marriage in the Early Empire should not easily be taken. ${ }^{2}$ These are, on the one extreme, the opinion that references to the practice have a basis only in literature and that the practice was rare and condemned, and on the other, that the practice was common and unproblematic. ${ }^{3}$ I submit instead that, while same-sex marriage certainly had a form of existence in Roman society, the widespread opposition to it had deep roots in the Roman conception of masculinity vis-à-vis homosexual desire, and that such opposition, being both sociocultural and legal, precluded an institutional existence. In what follows, three references to the practice in Martial, Juvenal and Suetonius are considered. I have chosen to focus specifically on these three authors since they present the clearest references to same-sex marriage which also contain some form of authorial opinion. They are also the only texts from the early Empire that refer explicitly to the practice. ${ }^{4}$

Martial Epigram 12.42

Like Catullus, Martial's sharp and explicit wit is oft exercised against the pathic homosexual. ${ }^{5}$ In Epigram 12.42, he derides a same-sex marriage:

2 Male same-sex marriage only, of course. Taking into consideration the paucity of textual evidence for Roman female homosexuality relative to the male, alongside the scarcity of references to male homosexual marriage, it is not surprising that women in this context are not mentioned. The reader is thus asked to supply 'male' alongside the phrases 'homosexual' or 'same-sex' throughout this essay in order to avoid cumbrous periphrasis.

3 The irenic handling of Juvenal's second satire by Eskridge 1993 is particularly bad. His fanatical and uncritical acceptance of Boswellian themes does not serve Boswell's memory well. With specific regard to same-sex marriage, as opposed to homosexuality more general, Boswell's later work, Same-sex unions in pre-modern Europe (1994) is a useful corrective to the earlier Christianity, social tolerance \& homosexuality (1980), even if one does not agree with all his assertions.

4 Other close references are Cic. Phil. 2.44, where Mark Antony is depicted as being given the matronly stola and being settled in matrimonio by Curio, and then the constitution of 342, which laments cum vir nubit in feminam. Both are disqualified from comment in this essay by their dates, but it should be added that neither are particularly useful. Cicero is, after all, arguing a legal case with all the prosecutorial invective one would expect, and the constitution of Constantius and Constans is not necessarily related to same-sex marriage; Cantarella 1994:175-176 argues that nubere here simply means 'coupled' while Boswell 1994:85-86 argues, persuasively and with some textual evidence, that the marital sense is to be retained. The same-sex marriages of Elagabalus (see footnote 11 below) add nothing to the argument not already added by Suetonius.

5 For a few examples from his epigrams, see 3.72, 7.58, 11.88; cf. Hubbard 2003:423-427. For Catullus, see poems 29 and 57. 
barbatus rigido nupsit Callistratus Afro

hac qua leqe viro nubere virgo solet

praeluxere faces, velarunt flammea vultus,

nec tua defuerunt verba, Thalasse, tibi

dos etiam dicta est. nondum tibi, Roma, videtur

hoc satis? expectas numquid ut et pariat?

Bearded Callistratus has married stern Afer

with that law wherewith a man is accustomed to marry a maiden.

Torches light up the way, veils cover the face, and words to you, oh Thalassius, are not lacking.

Even a dowry is announced. Is this yet not enough for you, oh Rome? Are you waiting for him to give birth?

$$
\text { Epigr. } 12.42
$$

Forming a doubled set around the marital verb nubere, Martial denotes the couple first by appearance and then by name. The prior is uncharacteristically symmetrical, given that hairiness was a standard mark of masculinity. ${ }^{6}$ For both partners to be described in so virile a fashion would appear at first to denote an equal partnership, but the inherent asymmetry of Roman marriage immediately returns as the marriage is performed qua lege viro nubere virgo solet, with the vir / virgo pair as traditional as everything that comes after: torches, veil, ritual invocations and dowry (faces, flammea, Thalassio, dos).

After this description, the ironic whip cracks. Martial asks a rhetorical Rome if this does not seem to her to be quite enough, and then, in a theme echoed in Juvenal below, mocks the sterility of the marriage. This simply follows the ambit of description. We have vir and virgo, we have all the accoutrements of traditional marriage, and now, as would be expected, there should be children. But clearly there cannot be. Martial points out to 'Rome' that such a marriage cannot fulfill all that marriage must be, even if the forms are obeyed.

In this respect, cf. Juv. Sat. 2.11-12 where bristly arms (proving a steadfast soul) are contrasted with a smooth anus (proving effeminate passivity); Ovid Ars. 3.437-8 where the smoothness of skin is an attempt to seduce men; Sen. Ep. Mor. 47.7 where a slave is restrained in an artificial boyhood via depilation; Martial Epigr. 10.65 where his contumax capillis is contrasted with the pathic's being levis. For the Greek use of hair growth as pederastic liminal sign, see the sections taken by Cantarella 1992:37-39 from the Greek Anthology. For the trope of hairlessness as attractive in a boy, see Richlin 1983:34-44. 
Juvenal Satire 2.117-140

Juvenal's second satire, in keeping with his brilliant use of inversion to make a moral point with derisive indignation, targets a group of men who subvert moral and social norms. ${ }^{7}$ In the midst of a lewd parody of the rites of the Bona Dea, a male couple is married:

quadringenta dedit Gracchus sestertia dotem cornicini, sive hic recto cantaverat aere; signatae tabulae, dictum 'feliciter', ingens

cena sedet, gremio iacuit nova nupta mariti. o proceres, censore opus est an haruspice nobis? scilicet horreres maioraque monstra putares, si mulier vitulum vel si bos ederet agnum?

Four hundred sesterces Gracchus gives as dowry to a horn-player (or perhaps he played a 'straight instrument'). The registers are signed, 'congratulations' are said, A great banquet is laid out, the newly wed wife reclines in the lap of her husband.

$\mathrm{O}$ forefathers, do we need a censor or an augur?

Perhaps you'd think it a horror or a greater monstrosity

If a woman gave birth to a calf, or a cow to a lamb?

Sat. 2.117-122

Juvenal's inversion pertains not only to gender-role but also to status: a socially distinguished groom marries a man of markedly inferior social standing: a mere musician. ${ }^{8}$ Then, as in Martial but with more detail befitting the narrative form, a series of traditional marital accompaniments is given, yet here the accompaniments are not ritual / ceremonial, but all social / cultural: the signing of registers (signatae tabulae), congratulations (dictum 'feliciter'), a sumptuous banquet (ingens cena sedet), and public displays of sentimentality (gremio iacuit nova nupta ${ }^{9}$ mariti). In his derision, Juvenal surpasses Martial. He invokes those representatives of traditional mores, the Roman forebears, with rhetorical exasperation, wondering aloud if the remedy is to be legislative (censore) or

7 The levels of inversion masterfully layered in this satire would suffer from even the briefest of summaries; the reader will profit from even a quick pass through the text. For a close textual analysis, see Nappa 1998.

8 Hubbard 2003:435 notes that 400,000 sesterces 'was the amount necessary to qualify for equestrian status'. The distinguished tone supplied by Gracchi needs no comment.

9 Note the grammatical gender. 
religious (haruspice). He rails at the abnormality of the proceedings, asking if a woman birthing a calf and a cow a lamb would be a thing of greater terror. That not disbelief but horror is invoked by these images is clearly to be understood within the context of prodigia and their accompanying ill omen and social panic. But Juvenal is not done. He calls upon Mars to bear witness to the impiety:

... o pater urbis,

unde nefas tantum Latiis pastoribus? Unde

haec tetigit, Gradive, tuos urtica nepotes?

traditur ecce viro clarus genere atque opibus vir

... oh father of our city,

whence came this impiety to Latin shepherds? Gradivus,

how did this itch seize your descendants?

Look, a man of noble birth and wealth is given to a man!

Sat. 2.126b-129

It may legitimately be asked at this point if what Juvenal is decrying is not the gender of the spouses, but their disjointed social status. Or, stated in textual terms, that Juvenal does not decry that traditur viro vir, but rather that traditur viro clarus genere atque opibus vir. The context, however, opposes such a reading. One could imagine aspersion cast on an unbalanced match, even derision, but not disavowal of same-sex marriage as being an unnatural thing akin to a monstrum of cross species birth, especially when it is immediately followed by an invocation of the most virile of gods. Juvenal is simply proficient at his art, and therefore layers irony upon satire. ${ }^{10}$ The disjoint of status and riches is aggravation, not cause. But Juvenal is still not done with the marriage and continues with an imagined conversation:

\section{... 'officium cras}

primo sole mihi peragendum in valle Quirini'. quae causa officii? 'quid quaeris? nubit amicus nec multos adhibet'. liceat modo vivere, fient, fient ista palam, cupient et in acta referri.

10 An excellent example in the selfsame piece is that Laronia, a prostitute, is lecturing on morals, recalling the Lex Scantinia in lines 43-45. The satirical effect could still have worked without this irony, but the effect is ingenuous. Another example within the text as given is the cornicinus, whose profession is punned upon lewdly (i.e. what kind of 'straight bronze' is he 'playing' with his mouth?). The satire's form only demanded a man (inverting gender) and an inferior (inverting status); Juvenal does both, and is explicit as well! 
interea tormentum ingens nubentibus haeret quod nequeant parere et partu retinere maritos. sed melius, quod nil animis in corpora iuris natura indulget: steriles moriuntur ...

... 'I've got some business tomorrow at dawn in the forum'. What business? 'Why do you ask? A friend is getting married. There won't be many attending'.

If there is yet longer to live, this'll happen, it'll happen in public, and they'll want to have it as public record.

Yet for all this, the brides are stuck with a terrible difficulty:

They cannot bear children and in the bearing retain their husbands. It is well that nature grants not a whit of power over their bodies to their souls: they die barren ...

$$
\text { Sat. } 6.132 \mathrm{~b}-140 \mathrm{a}
$$

The nonchalance is marked with apprehension: What is first merely some business in the forum (peragendum in valle Quirine) will surely in time become a public affair (fient ista palam) and then not merely public but seeking public recognition (cupient et in acta referri): a kind of 'slippery slope' from private celebration to socio-legal approval. Against this crescendo, Juvenal counterpoints two attributes which should happily lead to the downfall of the practice: one, that the brides will not be able to hold onto their husbands by means of the production of children (partu ritenere maritos), and two, that the union will end without issue (steriles moriuntur). Juvenal's treatment of this 'marriage' is thus doubly parodic: firstly, it occurs as an all-male celebration of the rites of the Bona Dea which belong exclusively to the female domain; secondly, it is depicted as being completely foreign to Roman conceptions of marriage.

\section{Suetonius Nero 28-29}

A final example comes from Suetonius, whose biographical writing often uses the lives of the emperors as negative moral exempla. Nero's libertine dalliances understandably yield a rich crop of censure in the Suetonian account. Of particular interest to us are his two same-sex marriages:

Super ingenuorum paedagogia et nuptarum concubinatus Vestali virgini Rubriae vim intulit. Acten libertam paulum afuit quin iusto sibi matrimonio coniungeret, summissis consularibus viris qui regio genere ortam peierarent. Puerum Sporum exsectis testibus etiam in 
muliebrem naturam transfigurare conatus cum dote et flammeo per sollemnia nuptiarum celeberrimo officio deductum ad se pro uxore habuit; exstatque cuiusdam non inscitus iocus bene agi potuisse cum rebus humanis, si Domitius pater talem habuisset uxorem. Hunc Sporum, Augustarum ornamentis excultum lecticaque vectum ...

Above and beyond the 'education' of freeborn boys and the 'concubinage' of married women, he raped the Vestal Virgin Rubria. He very nearly concluded a legitimate marriage with the freedwoman Acte, by bribing consuls to swear falsely that she was of royal birth. He tried to transform the boy Sporus into a woman by castration, married him in solemn ceremony with a dowry and veil, and took him home as his wife before a great gathering. Some witty wag's comment still survives: 'It would have been good for mankind had Domitius his father taken such a wife'. This Sporus he took around in his litter, arrayed in the ornaments of an empress.

Nero 28

In this account, Suetonius imputes to the Flavian emperor sexual activity with all manner of forbidden partners: freeborn boys (ingenui), married women, a Vestal Virgin, and then relates that Nero had married a boy named Sporus. This marriage is disparaged by Suetonius on every side: the marriage is prefaced by an attempt at feminization (in muliebrem naturam transfigurare conatus), and one is led, by the repeated stress on externals, to be dismissive. Suetonius even goes as far as to relate a witticism that had crystallized public disapproval. Just a little further on, another marriage occurs, but the roles are then reversed: ${ }^{11}$

[Doryphoro liberto] etiam, sicut ipsi Sporus, ita ipse denupsit, voces quoque et heiulatus vim patientium virginum imitatus.

[The freedman Doryphorus], just as he had with Sporus, took him as wife, and [Nero] imitated the cries and wailings of a virgin suffering violence.

Nero 29

11 This atypical disregard for roles occurs again with the emperor Elagabalus, who also had 'marriages' where he had been both 'husband' and 'wife'. Dio Cassius 80.14-15 is as dismissive as Suetonius is with Nero; Cf. Boswell 1994:83-85 for discussion and further references. It would be foolish not to call these marriages, given the use of the verbs غ่үท́ $\mu \alpha \tau$ and nupsit. 
Two things are notable. First, the stress on Doryphorus' status as a freedman, and second, that the delegitimizing vocabulary of Suetonius is present here also: Nero is said to imitate the cries of a virgin.

\section{A question of materiality}

It may be asked whether such textually depicted marriages had any real life referents, since ironic epigram, satire and biased history are hardly sources to be taken as self-evidently true. However, the very nature of satirical humour must be kept in mind: wit presupposes the existence of what is maligned, whether objectively or subjectively, that is, in actual social existence, or as a social construct: a fictive peg on which to hang the joke. ${ }^{12}$ Whether same-sex marriages existed objectively need not, in the strictest sense, be proved here, since I merely wish to detail the nature of the opposition to such a practice. I would still contend, however, that the level of complementary detail in both Juvenal and Martial militates against a purely subjective existence, as does the personalised narrative of Suetonius with its focus on externals and merely social approval. ${ }^{13}$ Furthermore, it has been argued that not only do these references in Juvenal point to actual social happenings, but also to the possible existence of pathic subcultures. ${ }^{14}$ At the very least, the arguments for the immateriality of the cinaedus are weak. ${ }^{15}$

12 Consider, in a South African context, the satirical works of hayibo.com and the comedy acts of Trevor Noah, both of which rely on the image of the corrupt politician. It would be futile to argue from these back to specific corrupt politicians, or to say that all politicians are corrupt or considered corrupt, but what is absolutely necessary for comic potential is a widespread subjective belief in the existence of corrupt politicians. Similarly, then, while we cannot argue on the basis of these three texts by Martial, Juvenal and Suetonius that same-sex marriage existed, much less that it was widespread, we cannot deny that in the minds of at least some of the respective recipients, same-sex marriage had occurred in Rome in roughly the forms decried.

13 Also, Suetonius is substantiated in his account by Dio Cassius and Tacitus. See Boswell 1994:80 for references.

14 Cantarella 1992:153: 'We are... compelled to cut [Juvenal's] denunciations down to size. This does not detract from the fact that his accusations point to a trend, an attitude, a style of behaviour which is not only real but now openly recognisable. The practices he describes are undoubtedly less widespread than his works would suggest, but they are neither negligible, nor marginal, nor exceptional'. See further Taylor 1997:338-340, and Richlin 1993:541-554.

15 See Richlin 1993 for a proper handling of the subject. 


\section{The arguments against same-sex marriage: Subjection and sterility}

The texts discussed above raise two aspects of same-sex marriage which would have been considered fundamentally problematic in a Roman context. The first aspect is that the feminization of one of the partners is assumed. The relational asymmetry of the Roman marriage partnership is well-documented, as is the fundamental asymmetry of homosexual activity. ${ }^{16}$ This asymmetry follows organically from the conception of the Roman sexual male as active in essence, with gender being less important. ${ }^{17}$ It is therefore acceptable to have sexual relations with male or female, as long as the Roman male remains the penetrator and not the penetrated. ${ }^{18}$ Furthermore, the object of one's sexual desire and activity

16 Ancient homosexual relationships are asymmetrical in general, but the issue remains disputed. Boswell 1994:57-58, in arguing that it is "probably wrong to imagine that

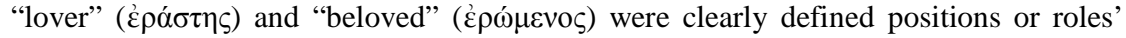
states that "since the affections at issue in the vast majority of Greek literature are those of adult males who would admit only an active role, the "beloved" must necessarily appear ... younger'. This is of course a fortiori true of the Romans (see footnote 19). Against this general position of inequality, Boswell argues that frater can be a term of egalitarian homosexual endearment (ibid., 67-72). He does so persuasively, but his literary exempla, apart from the Satyricon, are not as clear cut as his arguments. He is far clearer later on, and provides the implicit solution to the problem, when he says: 'A large part of the reason sexuality would complicate an ancient friendship is that the primary and defining characteristic of friendship ... was its inherent equality ... Since most ancient concepts of male sexuality presupposed that the "active" or insertive party somehow dominated the "passive" or receptive partner, sex would appear to introduce an element of subordination or inequality into a friendship, and thus complicate it'; ibid. 79.

17 This is negatively supported by the 'active' prostitute Naevolus in Juvenal's ninth satire; cf. Cantarella 1992:154: 'Male prostitution, as we know, had always been widespread in Rome. But in the old days, boys sold themselves to be subjected to sex like women. Their paymaster was still a real man. Now, everything has changed. Naevolus is an active homosexual. The Romans have sunk to such a level of depravity that they no longer pay to put somebody else underneath them - they now pay someone to go on top. The ideology, then, has not changed: a man is only a real man if he is gloriously active'. This horror at the sexual subjection of the male makes intelligible the fact that in the ladder of insults and threats, being forced to perform oral sex on another man is a worse fate than forced anal penetration. See, for instance, the threats of the god Priapus to violators of his garden: 'You, who scheme evilly and try derangedly to steal from the garden, will be buggered by my yardstick. If so serious and heavy a punishment doesn't do the trick, I'll reach higher' (Priapea 28). Being the subject of irrumatio is thus worse than pedicari. Modern verbal forms describing oral sex denote the active / passive inversely to the Roman conception, and are thus a source of confusion: the act was viewed not in the modern paradigm of pleasure-by-stimulation, but in the paradigm of pleasure-by-penetration. 
must not violate another man's domain: married women, freeborn boys and the slaves of others are forbidden, whereas your own wife, slaves, concubines and prostitutes are permissible. ${ }^{19}$

It is pithily summarized in Plautus: $:^{20}$

No one forbids anyone from going along the public path,

As long as you don't make a footpath through enclosed land, as long as you abstain from the bride, the widow, the maiden, ${ }^{21}$ the youth and free boys, love as you like.

$$
\text { Curc. } 35-38^{22}
$$

The conception of same-sex marriage is thus problematic since it involves the subjection of one man's potestas to that of another, which is reprehensible in a free-born. ${ }^{23}$ That the distinction of the free-born was pivotal to the Romans is

19 This rendering of the freeborn youth (ingenuus) as removed from permissible sexual dalliance is one of the chief differences between Greek and Roman homosexual mores; It would be inconceivable that something like the Lex Scantinia could become law or custom in a Classical $\pi$ ó $\lambda$ is (see footnote 33 for references). It is instructive to note how this follows socio-political concerns. For the Greek, the purpose of the $\pi$ ó $\lambda 1 s$ was the achievement of the $\kappa \alpha \lambda$ ó $\varsigma \kappa^{\prime} \alpha \gamma \alpha \theta$ ó $\varsigma$, and this was launched by the system of $\pi \alpha 1 \delta \varepsilon i ́ \alpha$ for the young boy. The idealization of homosexual relations as facilitating the pursuit of $\dot{\alpha} \rho \varepsilon \tau \eta \dot{~ i s ~ t h u s ~ u n s u r p r i s i n g, ~ a n d ~ w o u l d ~ b y ~ i t s ~ n a t u r e ~ i n c l u d e ~ t h e ~ f r e e b o r n ~ c i t i z e n ~ a s ~ h e ~ i s ~}$ the natural aspirant thereof. The Roman, however, was characterized in his highest literature as being required parcere subiectis et debellare superbos, and thus dominance is the hallmark of his sexual ethic. To dominate one who would himself be required to dominate in future is therefore not acceptable. For a good synopsis of texts supporting the inviolability of 'Roman blood', see Cantarella 1992:104-106.

20 Cantarella 1992:115-119 connects the forbidden categories here to the content of the praetorian edict De Adtemptata Pudicitia. She persuasively uses this to date the edict to thirty years after the promulgation of the Lex Scantinia, which she places circa 227 BC; for discussion, see Cantarella 1992:110-111; 118-119.

${ }^{21}$ All three under the manus of others. This was more common in Plautus' era, where marriage cum manu was normal. By the era we are discussing here, it has been replaced by a marriage based more on consent than a transferral of the woman into the family of her husband. This newer conception of marriage had as a result the fact that her father still had potestas over his daughter, to the point of interrupting the marriage; cf. Cantarella 2002:272-273.

22 Nemo ire quemquam publica prohibet via; / dum ne per fundum saeptum facias semitam, / dum ted apstineas nupta, vidua, virgine, / iuventute et pueris liberis, ama quidlubet.

23 Even Boswell 1994:83 notes this: 'The fact that in heterosexual unions the woman was given, by the male who owned or controlled her, into the control or ownership of another male nonetheless posed some problems for any same-sex unions drawing on their symbolism or authority ... In the case of two males, which one would yield control?' 
supported by Plutarch in a striking way, when he describes the rationale for the wearing of the golden bulla by free-born boys: ${ }^{24}$

Indeed it was neither unseemly nor shameful for the men of old to love household slaves who are in their prime. Do not even the comedies nowadays bear witness of this? Free boys, however, they vigorously avoided, and for this reason the boys wore this sign, so that men would not be uncertain if they chanced upon them naked.

\section{Roman questions $288 \mathrm{~A}^{25}$}

The second problematic aspect of same-sex marriage, referenced so sharply by both Juvenal and Martial, is that of sterility. Attitudes towards marital purpose or even the very existence of marriage are not homogenous, even if one considers only the early Empire, yet it is clear that official state policy followed the Augustan trajectory of reverence for marriage. The mos maiorum regarded marriage as being necessary and necessarily fertile. ${ }^{26}$ The episode of Cato the Younger, who handed his wife Martia over to his friend Hortensius for no greater reason than Hortensius' need and desire for offspring, is incomprehensible without the Roman focus on marriage as procreative institute. ${ }^{27}$ Many legal texts support this. For example, an inheritance would be left on the proviso that the wife remarried and bore children. ${ }^{28}$ This insistence on marital issue is easily understandable. Stability of the Empire required stability of dynasty and inheritance, and the rearing of Roman sons is a familiar trope. ${ }^{29}$

24 As Cantarella 1992:100 notes, this is unlikely to be the true origin of the bulla, but it is nonetheless apposite that Plutarch should so explain it.

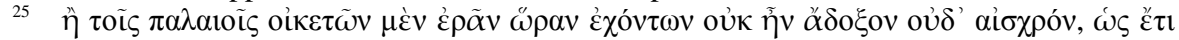

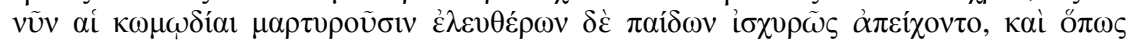

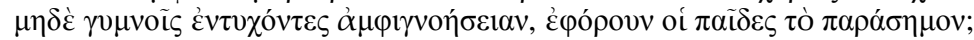

26 The Augustan programme was positive in the sense of promoting marriages and childrearing under the auspices of traditional Roman morality (such as the Lex Papia), and negative in the sense of legislation taking over sociocultural proscription (such as the Lex Iulia which is also referenced in Juvenal). Cantarella 1992:142-145, who specializes in Greco-Roman Law, situates the Lex Iulia correctly in context.

27 For an excellent analysis of the entire story, see Cantarella 2002:269-282.

28 Cantarella 2002:277-278 displays her usual proficiency with legal texts as she discusses this.

29 The fact that intestabilis is social sanction alongside infamis is instructive. For infamia in this context, see below. For the rearing of sons, cf. Cantarella 2002:277 : ' ...for the sake of the city, no reproductive ability should be wasted. It was almost as if women able to have children were an endangered species and the law had taken it upon itself to help them (or sometimes to oblige them) to do their childbearing duties'. 
There were other streams that followed this thought even further. ${ }^{30}$ Musonius Rufus, for example, claimed that sexual activity is impermissible outside the marital bond, and even within it permissible only for the purpose of procreation:

Men who are not wantons or immoral are bound to consider sexual intercourse justified only when it occurs in marriage and is indulged in for the purpose of begetting children, since that is lawful, but unjust and unlawful when it is mere pleasure-seeking, even in marriage. But of all sexual relations those involving adultery are most unlawful, and no more tolerable are those of men with men, because it is a monstrous thing and contrary to nature. But furthermore, leaving out of consideration adultery, all intercourse with women which is without lawful character is shameful and is practiced from lack of self-restraint ...

What need is there to say that it is an act of licentiousness and nothing less for a master to have relations with a slave? Everyone knows that.

\section{On sexual matters $12^{31}$}

It serves Musonius' purposes to declare that his opinions are common, so a grain of salt may be indicated. However, for at least Stoic philosophers, who were indeed quite popular and influential in the Rome of the time, it was common to view sexual activity and marriage (like almost all things) through the lens of enkrateia vs. self-indulgence. The Roman Stoics, in contrast with the Greek origins of their school, were not positively inclined towards homosexual relations. Certainly Musonius and Seneca are vigorous in their disapproval of such as being contra naturam. $^{32}$

30 And streams that only begrudgingly went that far. Some philosophers viewed marriage as a necessary evil with which the utopian society would dispense; cf. Bosman 2010:1013 for discussion. Basically, Zeno dispensed of marriage in his utopia, Musonius considers present reality to be reconcilable with marriage, whereas Epictetus views marriage as best avoided in the current 'battle' of reality.

31 Translation taken from Hubbard 2003:394.

32 Cf. Sen. Ep. Mor. 122.7: Non vivunt contra naturam qui spectant ut pueritia splendeat tempore alieno? Quid fieri crudelius vel miserius potest? numquam vir erit, ut diu virumpati possit? et cum illum contumeliae sexus eripuisse debuerat, non neaetas quidem eripiet? ('Do they not live contrary to nature who see to it that boyhood shines out at a different time? What can be more cruel or wretched? In order to suffer men will he then never become a man himself? And when his sex suffices not to snatch him from this outrage, will not even adolescence?'). The phrase contra naturam is almost a refrain in this section of the letter. Cantarella provides an exceptionally clear and straightforward consideration of early Christian approaches. On the Judaic front, she is 
On the legal front, the Lex Scantinia, even considering the muddied waters of scholarship around it, seems to have punished sexual passivity by freeborn Roman citizens. ${ }^{33}$ What is not doubtful is that punishments for sexual passivity did indeed occur, and that prosecutorial rhetoric around the passivity of the accused in his youth formed almost a locus communis. Cicero employed it often. ${ }^{34}$ It is also instructive to consider the punishment of infamia in relation to passive homosexuality: the penalties were not criminal but entailed a loss of civil status and concomitant rights. ${ }^{35}$ That the application was ad hoc does not diminish the social censure they imply. If anything, the sanction of infamia subjects the male 'who has undergone womanly actions in his body' to severe societal disapproval that did not need explicit legal sanction. ${ }^{36}$

\section{Conclusion}

On the basis of the evidence presented here, it may be concluded that while samesex marriage had some presence in early Imperial Rome, this presence was restricted to decadent or parodic manifestations, and was perceived as inverting the natural and social orders. Juvenal derides such a marriage as a monstrum and approvingly notes that such marriages must fall short by their inherent failure to produce legitimate offspring, even as he wonders with alarm if the practice could not become common and public. Martial, for his part, is as sarcastic as he is

in substantial accord with Satlow 1994, who gives more detail. With regard to the relative uselessness of talking about a mainstream 'natural' / 'unnatural' dichotomy, see Richlin 1993:533 n. 25: ' $\ldots$ the conception of naturalness takes a larger and more ominous form in our post-Christian culture than it did in antiquity, where it was a matter for philosophers'.

33 For its legendary origin, see the tale of C Scantinius Capitolinus in Valerius Maximus 6.1.7, who was legally charged for attempting stuprum with a young freeborn boy. Regarding its legendary status, as Cantarella 1992:109 notes, it would be 'breaking the rule whereby laws took their names from their proposers rather than their targets', among many arguments. For the arguments around the dating, naming (Scantinia / Scatinia), and content, see Cantarella 1992:106-114. Richlin 1983:224 summarizes nicely when she says '.. . the lex Scantinia ... apparently made illegal the sexual abuse of an ingenuus by another male'.

34 Cicero's invective can thus not be considered legal opposition, since it properly belongs to self-interested moral rhetoric, and must thus be considered in the social or cultural stream of opposition. For examples, cf. Cat. 2.8; Red. Sen. 11; Har. 42, 59; Phil. 2.4445.

35 Richlin 1993:555-561 devotes some detailed space to the topic in this context.

36 eum qui corpore suo muliebria passus est. The phrase is taken from a praetorian edict in the Justinian Digest. For the argument that this particular content is conservatively Hadrianic, contra Boswell, see Richlin 1993:558 n. 84. 
derisive, and mocks the sterility of such a union. Suetonius places both Nero's same-sex marriages within the context of depravity and disregard for sexual norms. All of this indicates strong cultural bias against same-sex marriage in Roman society, which promoted marriage for reasons of social stability and held as sacred the sexual inviolability of the freeborn Roman male, which a same-sex marriage would by implication transgress. Philosophical condemnations, particularly the Stoic, tended to undergird the social status quo, whether in the form of subjecting the purpose of marriage to child-bearing, or by means of the not entirely unproblematic disparagement of homosexual relations as being contra naturam. Lastly, evidence of legal condemnation exists, formally in prosecution based on the Lex Scantinia and less formally in the sanction of infamia. Considering these legal and cultural aspects, it is clear that there would have been a formidable block to any institutional form or social sanction of same-sex marriage, and that whatever the form and frequency of the practice in the early Empire, it was never without opposition.

\section{BIBLIOGRAPHY}

Bosman, P R 2010. Utopia, domestication and special status: Marriage and family in the stoic tradition. Acta Patristica et Byzantina 21.2:5.

Boswell, J 1980. Christianity, social tolerance and homosexuality: Gay people in Western Europe from the beginning of the Christan era to the fourteenth century. Chicago: University of Chicago Press.

- 1994. Same-sex unions in premodern Europe. New York: Villard Books.

Cantarella, E 1992. Bisexuality in the ancient world. Translated from Italian by C Ó Cuilleanáin. London: Yale University Press.

- 2002. Marriage and sexuality in Republican Rome: A Roman conjugal love story. In: Nussbaum, M \& Sihvola, J (eds.), 2002. The sleep of reason: Erotic experience and sexual ethics in ancient Greece and Rome, 269-282. Chicago: University of Chicago Press.

Eskridge, W N 1993. A history of same-sex marriage. Virginia Law Review 79.7:1419.

Hubbard, T K (ed.) 2003. Homosexuality in Greece and Rome: A sourcebook of basic documents. Los Angeles: University of California Press.

Nappa, C 1998. 'Praetextati Mores': Juvenal's second satire. Hermes 126.1:90.

Richlin, A 1983. The garden of Priapus: Sexuality and aggression in Roman humor. London: Yale University Press.

- 1993. Not before homosexuality: The materiality of the cinaedus and the Roman law against love between men. Journal of the History of sexuality 3.4:523. 
Satlow, M L 1994. 'They abused him like a woman': Homoeroticism, gender blurring, and the rabbis in late Antiquity. Journal of the History of Sexuality 5.1:1.

Taylor, R 1997. Two pathic subcultures in ancient Rome. Journal of the History of Sexuality 7.3:319. 